\title{
Contracting Institutions, Property Rights and Economic Growth in the Post-90s Albania
}

\author{
Mario Curcija* (PhD) \\ University of Shkoder "Luigj Gurakuqi", Faculty of Economy, Albania
}

Doi: 10.19044/esj.2018.v14n1p176 URL:http://dx.doi.org/10.19044/esj.2018.v14n1p176

\begin{abstract}
Economists often emphasize the role of institutions in order to explain the difference in wealth and development among different countries and in their researches they mark correlation between institution and economic development. This paper tests the validity of these models referring to Albania using time-series data from 1993 to 2015. There is evidence of significant positive effect of property rights on economic growth and credit to private sector, while there is evidenced insignificant impact of contracting institutions on economic outputs. A plausible explanation of these differences may be the different flexibility towards changes on property right institution rather than contracting institutions.
\end{abstract}

Keywords: Institutions, economic growth, development, Albania

\section{Introduction}

Rule of law, safer property rights, political and economic freedom, government accountability, productivity of human capital, advanced technology etc. are considered to be drivers of economic growth (Schultz, 1961) (Barro, 1998) (Mankiw, Romer, \& Weil, 1992) (Dougherty \& Jorgenson, 1996) (Williamson O. , The New Institutional Economics: Taking Stock, Looking Ahead , 2000). The role of the institutions, especially, has gained consensus among economists and it has given rise to the new historical institutional economics as a perspective which extends economics to neglected fields of study such as history and culture (Rutherford, 2001).

Institutions are described as human constructs that define social, political, economic relations in order to create order and reduce uncertainty (North, Institutions, 1991). They are constituted by formal institutions such as constitutions, laws, property rights and informal institutions e.g. customs, doctrines, moral codes, etc. The state's different views, as a complex of formal institutions, are distinguished between the contract theory of state and the 
predatory theory of state (North, Structure and Change in Economic History, 1981).

According to the contract theory of state, enforcement of contracts is guaranteed by law enforcement fulfilled by formal institutions - the state which in the public consciousness is delegated and legitimized to exercise this function. The academic literature in the field of contract theory focuses on identifying the most efficient forms of contract and their enforcement due to the failure of one part because of insolvency, information asymmetry, incomplete contracts, opportunism etc. (Coase, The Nature of the Firm, 1937), (Coase, The Problem of Social Cost, 1960), (Williamson O. , The Economic Institutions of Capitalism, 1985), (Williamson O. E., 2002). The earliest forms of contract enforcement were not fulfilled by the state as a formal institution, but were carried out by informal institutions based on a series of informal rules and traditions (Greif, Contract enforceability and economic institutions in early trade: The Maghribi traders' coalition, 1993), (Greif, Milgrom, \& Weingast, Coordination, Commitment, and Enforcement: The Case of the Merchant. Guild, 1994), (Greif, Institutions and the Path to the Modern Economy: Lessons from Medieval Trade, 2006). From a historical point of view, formal institutions are a continuation, an acknowledgement of a now well-established and standardized situation, which merely certifies a set of rules already established among the operators. Critics of the description of natural evolution from informal to formal institutions, tend to underline the role of the state since the very early stage of economy (Ogilvie \& Carus, 2014).

According to the predatory theory of state, as far as the state is seen as the only authority legitimized to use force to provide peace, order and reduce anarchy, it may lead to tyranny. The exclusive right of the state to use force risks bringing authoritarianism and expropriation (Hobbes, 1991). From a Marxist point of view, the attributes of the state can be exercised by a group that transfers wealth from one group to the other, from which the predatory theory of state. The risk of expropriation may come as a result of excessive state presence in the economy - typical of authoritarian and dictatorial countries - which directly or indirectly e.g. through business connected to politicians can expropriate the individuals from their property or also from the lack of state presence, which exposes individuals to theft and robbery of property (Djankov, Glaeser, La Porta, Lopez-de-Silanes, \& Shleifer, 2003).

The importance of protecting the right of private property as a determining factor for growth and economic development is emphasized earlier by the classical economy (Smith, [1776] 1991) and especially by the Austrian school of economy as a necessary tool for satisfaction of his needs (Menger, [1871] 1976), stimulating human action (Mises, [1940] 1998) and as the most efficient way of transferring information among economic operators (Hayek, 1945). Private property protection and political pressure on the 
government, as a guarantee of the inviolability of private property, both from private or public abuse, has an important role in particular for countries in transition from communist dictatorships in the market economy (Olson, 2000). Private property warranties, legal property titles included in a set of constitutional rules that limit arbitrariness and abuse of political power, are considered a determining factor of economic development (de Soto, 2000).

The purpose of our study is the impact of the Contracting Institutions and Property Rights in the economy. I test the role of "contracting theory" and "private property rights" in the Albanian economy, within the framework developed by (Acemoglu, Johnson, \& Robinson, Institutions as a fundamental cause of long-run growth, 2005), which examines the impact that contracting institutions and property rights have in the economy of a country.

\section{Institutions in Albania}

Until 1990, Albania was part of those Eastern European countries that were under a political dictatorship, governed by a single communist party and had a central planned economy. The collapse of the totalitarian regime, as the last stage of a decline process, caused a fast transition from the centralized communist system to a market economy, although at that time the basic institutions of the market economy were still missing. The dismantling of the old system with the decline of the old formal institutions urged the development of new - formal and informal - institutions in the conditions of the adoption of liberal democracy and the market economy. The effects of the regime collapse were huge, beyond the plain dismantle and substitution of old institutions. As Eric Hobsbawn (1996) argues "The formal institutions overthrown or founded by a revolution are easily discernible, but they do not measure its effects" (p. 182).

No other phenomenon has characterized better the transition period from communism to liberal democracy than the massive population movement. Both immigration and internal migration of the population are a social phenomenon with consequences on the form and content of the institutions. It is estimated that 1 million Albanians, $1 / 3$ of the population, immigrated to western countries (Instat Albania, 2014). Of the same magnitude it was the internal migration, synonymous with urbanization. In Albania during the communist regime, there was a ban on leaving the countryside, so after the crumble of the communist regime in 1991, a huge mass of extremely poor rural people moved toward the cities. Besides the police control over the population movement, there were two other ways by which the communist regime curbed the free movement.

The first relates to labor rights. In Albania, as in every other country with a centralized Marxist planned economy, all enterprises were public and employment in any enterprise was a consequence to the authorization of local 
communist organs, which at the same time authorized the right of residence in their area. Labor mobility was constrained, because political power had predominance on management, e.g. Chief personnel were appointed by the political office rather than by the management of the enterprise. Consequently, the autonomy of management to hire the workers they wanted was limited.

The second aspect relates to the fact that private property did not exist; with the exception of the house yards, all the property belonged to the state. New residential buildings were built by the state based on central planning, which restricted free movement. With the collapse of the communist regime arose the problem of the legal treatment of the change of property from public to private hands. The main problem relates to the fact that, as far as during the 45 years of communist regime the private property did not exist, the former owners who had been seized according to the Soviet model, could not even imagine to make a last will and testament of their lost and confiscated properties. The lack of testamentary acts raised the problem of accurate identification of the former owners' heirs. Issues with return of property to former owners, the legal vacuum regarding the status of former agricultural cooperatives - whether public or private - without a clear recognized ownership, favored the squatter by thousands of families that, taking advantage from the abolition of restrictions on free movement, decided to leave rural poorer areas. This massive phenomenon of internal migration involved the western area of Albania and the peripheries of large cities, whose dimensions increased sharply from the influx of people coming from the hinterland areas of Albania. The emblems of this swift development are the informal areas around the peripheries; between 1991 and 2014 there were 427 thousand illegal buildings, most of which completely informal (ALUIZNI, 2015).

If informality on one hand has prevented the abusive interventions of a public administration among the most corrupt in Europe (Transparency International), on the other hand prevents the positive effects of property involvement in the legal system (de Soto, 2000). Nevertheless economic operators have shown a great deal of vitality, energy and fantasy to face the conditions of a market not perfect in the classical sense of the word. The lack of formalization of property titles, political instability, the fragility of the rule of law, the constant risk of demolition of informal construction by authorities, lack of roads, water and electricity networks have not stopped the development of the economy. Although a large part of the Albanian economy lies under the shadow of informality, which reaches up to $40 \%$ of Gross Domestic Production (Buehn \& Friedrich, 2010), throughout the 1990 to 2016 period the economy has experienced continuous growth, poverty reduction and an increase in wellbeing (The World Bank). This demonstrates there is a set of 
informal institution made of rules, traditions, social norms that are created spontaneously among the operators, who relate constantly with each other.

\section{Basic specifications}

In their paper (Acemoglu \& Johnson, Unbundling Institutions, 2005), represent a linear relationship between economic growth and institution's quality: $Y i=\alpha \cdot F i+\beta \cdot I i+Z i \cdot \delta+\varepsilon i$, where $Y i$ - output of interest, $F i$ measure of contracting institutions, $I i$ - measure of property rights institutions and $Z i$ vector of other variables.

In this paper, the outcome of interest are the level of GDP per capita as a measure of long-run growth, the domestic credit to the private sector as a percentage of GDP and the ratio of investment to GDP. Stock market capitalization is not considered in this work as there is not a stock market in Albania.

Regarding to the ratio of investment to GDP, in this paper are used World Bank indicators - Gross Domestic Investment and Gross Fixed Capital Formation. According to Hernando De Soto - "The Mystery of Capital", insecure property rights influence the behavior of investors, so that accumulated wealth is not invested in long term capital, but it is held as much liquid as possible. Uncertainty and risk of expropriation - weak property rights - discourages individuals from capital investments. Conversely, improvements in property rights in developing countries discourage individuals from shortterm inventories and encourage capital accumulation and long-term fixed capital investments. To test this hypothesis Kerekes \& Williamson (Unveiling de Soto's Mystery: Property Rights, Capital, and Development, 2008) used as output variable the Gross Capital Formation and Gross Fixed Capital Formation as a percentage of GDP. GCF besides fixed assets measured by GFCF includes also changes in the level of inventories. Breaking down the investment ratio to GDP in two indicators allows us to see the impact that property rights institutions have on the structure of invested capital. The expectation is that an improvement in property rights will have a positive impact on the overall investment ratio, and, in particular this impact is predicted to be greater in GFC, because trust of individuals towards institutions as a guarantor of private property rights grows, which shifts_capital from short-term liquid assets to long-term fixed assets.

In the original model of Acemoglu \& Johnson, Polity IV Index and the Heritage Property Index are used as proxy for property to measure the property rights protection, because they are considered constrains on executive. The Political Risk Service Assessment is not considered, as it did not measure almost any change over the years in Albania. The World Bank "Enforcing Contracts" and "Resolving Insolvency" indexes are used as proxy for contracting institution. 
In the original model among control variables, there are included government consumptions as a percentage of GDP, inflation, geography, legal origin, ethno linguistic fractionalization. Since that in this paper Albania is the only country, government consumptions and inflation are the only control variables. Instrumental variables "the average life expectancy of the first colonies" used as the property development level matrix in the two-stage-leastsquare model of Acemoglu \& Johnson model doesn't apply in this paper.

\section{Data Analysis}

In order to run the tests, a time-series dataset for Albania is constructed, based on World Bank's annual and averaged data for the period $1993-2017$.

Table 1 Descriptive Statistics

\begin{tabular}{c|ccccc}
\hline Variable & Obs & Mean & Std. Dev. & Min & Max \\
\hline LnGDPperca $\sim \mathrm{P}$ & 23 & 8.621 & .5412132 & 7.681 & 9.328 \\
Domesticcr $\sim \mathrm{r}$ & 22 & 1.924 & 15.471 & 3.179 & 39.460 \\
Grosscapit $\sim \mathrm{P}$ & 23 & 2.951 & 7.981 & 13.2 & 40.472 \\
Grossfixed n & 23 & 2.894 & 7.923 & 13.2 & 40.472 \\
PolityIV & 23 & 7.173 & 1.898 & 5 & 9 \\
HPIoverall $\sim \mathrm{e}$ & 22 & 59.65 & 5.215 & 49.7 & 66.9 \\
EnforcingC F & 14 & 58.110 & 2.555 & 53.66 & 60.52 \\
ResolvingI F & 14 & 33.379 & 20.517 & 19.79 & 64.98 \\
Government $\sim \mathrm{t}$ & 23 & 10.966 & 1.280 & 9.195 & 14.128 \\
LnInflation & 23 & 1.319 & 1.044 & -.4148224 & 37.394 \\
\hline
\end{tabular}

Table 2 Property Rights Institutions

\begin{tabular}{|c|c|c|c|c|c|c|c|c|}
\hline & \multicolumn{2}{|c|}{$\begin{array}{l}\text { Log GDP per } \\
\text { capita PPP } \\
\text { current } \$\end{array}$} & \multicolumn{2}{|c|}{$\begin{array}{l}\text { Domestic credit to } \\
\text { private sector } \\
(\% \text { GDP })\end{array}$} & \multicolumn{2}{|c|}{$\begin{array}{l}\text { Gross Capital } \\
\text { Formation } \\
(\% \text { of GDP) }\end{array}$} & \multicolumn{2}{|c|}{$\begin{array}{l}\text { Gross Fixed } \\
\text { Capital } \\
\text { Formation } \\
\text { (\% of GDP) }\end{array}$} \\
\hline & 1 & 2 & 1 & 2 & 1 & 2 & 1 & 2 \\
\hline Polity IV & $\begin{array}{c}.22 * * * * \\
(.02)\end{array}$ & & $\begin{array}{c}7.62 * * * \\
(1.03)\end{array}$ & & $\begin{array}{l}1.19 \\
(.90)\end{array}$ & & $\begin{array}{c}.84 \\
(.94)\end{array}$ & \\
\hline Heritage Property & & $\begin{array}{c}.082 * * * \\
(.004)\end{array}$ & & $\begin{array}{c}2.90 * * * \\
(.24)\end{array}$ & & $\begin{array}{c}.05 \\
(.34)\end{array}$ & & $\begin{array}{l}-.088 \\
(.35)\end{array}$ \\
\hline $\begin{array}{l}\text { Governm. } \\
\text { Consumption } \\
(\% \text { of GDP })\end{array}$ & $\begin{array}{l}-.05 \\
(.02)\end{array}$ & $\begin{array}{c}.01 \\
(.02)\end{array}$ & $\begin{array}{c}.20 \\
(1.41)\end{array}$ & $\begin{array}{c}1.87 \\
(1.26)\end{array}$ & $\begin{array}{c}- \\
1.89 * \\
(1.09)\end{array}$ & $\begin{array}{l}-1.05 \\
(1.76)\end{array}$ & $\begin{array}{l}-1.91 \\
(1.14)\end{array}$ & $\begin{array}{r}-1.20 \\
(1.7)\end{array}$ \\
\hline Log Inflation & $\begin{array}{l}-.10 * * \\
(.04)\end{array}$ & $\begin{array}{l}-.09 \\
(.02)\end{array}$ & $\begin{array}{c}.64 \\
(2.02)\end{array}$ & $\begin{array}{c}.64 \\
(1.42)\end{array}$ & $\begin{array}{l}-2.33 \\
(1.69)\end{array}$ & $\begin{array}{l}-2.94 \\
(1.98)\end{array}$ & $\begin{array}{l}-2.48 \\
(1.76)\end{array}$ & $\begin{array}{l}-3.17 \\
(2.02)\end{array}$ \\
\hline R-square & 0.92 & 0.96 & 0.81 & 0.91 & 0.46 & 0.16 & 0.40 & 0.14 \\
\hline
\end{tabular}

Notes: Standard errors in parentheses. Significance level: *** at $1 \%, * *$ at $5 \%, *$ at $10 \%$ 
Table 2 shows OLS regression between the property rights proxy index and respectively log GDP per capita, credit to the private sector and ratio investment to GDP.

Regarding property rights institution, both the Polity IV and the Heritage Property Index show that there is a positive and significant relationship between the strengthening of property law institutions and two outcomes, economic growth and credit to private sector. In assessing the marginal effect for Polity IV or Heritage Property, it should be considered the different range of the indicator; Polity IV takes values ranging from -10 to +10 , while HPI from 0 to 100 .

Relationship of property rights with GDP growth per capita is significant and positive, but modest; an increase of 4 units in the Polity IV Index, or the HP Index equivalent of 16 units, has an impact of $+1 \%$ in the GDP per capita.

Regarding domestic credit the relation with the property rights index is positive, significant and of great economic magnitude. A unit increase in the in the Polity IV Index, or the HP Index equivalent of 4 units, has an impact of $+8 \%$ in the domestic credit to private sector.

There is no evidence to support the expectations that an increase in the protection of private property rights would lead to an increase in the ratio of investment to GDP. None of the interested variables shows any correlation with the property rights index.

Table 3 Contracting Institutions

\begin{tabular}{ccccccccc}
\hline \hline & $\begin{array}{c}\text { Log GDP per } \\
\text { capita PPP } \\
\text { (current \$) }\end{array}$ & $\begin{array}{c}\text { Domestic credit } \\
\text { to private sector } \\
(\% \text { GDP) }\end{array}$ & $\begin{array}{c}\text { Gross Capital } \\
\text { Formation } \% \\
\text { of GDP) }\end{array}$ & $\begin{array}{c}\text { Gross Fixed } \\
\text { Capital } \\
\text { Formation } \\
\text { of GDP) }\end{array}$ \\
& 1 & 2 & 1 & 2 & 1 & 2 & 1 & 2 \\
\hline Enforcing Contracts & -.056 & & -1.15 & & $1.34^{*}$ & & 1.37 & \\
& $(.045)$ & & $(2.30)$ & & $(.68)$ & & $(.85)$ & \\
Resolving Insolvency & & .008 & & .24 & & $-.17 * *$ & & $-.19^{*}$ \\
Governm. & & $(.004)$ & & $(.25)$ & & $(.07)$ & & $(.08)$ \\
Consumption & .055 & .034 & 1.77 & 1.76 & -4.39 & -3.81 & -4.96 & -4.47 \\
(\% of GDP) & $(.19)$ & $(.17)$ & $(9.69)$ & $(9.11)$ & $(2.89)$ & $(2.59)$ & $(3.60)$ & $(3.17)$ \\
Log Inflation & -.014 & .012 & -1.52 & 1.24 & .86 & .72 & .27 & -.42 \\
R-square & $(.24)$ & $(.22)$ & $(12.50)$ & $(11.4)$ & $(3.73)$ & $(3.25)$ & 4.64 & $(3.97)$ \\
Not & 0.27 & 0.35 & 0.07 & 0.14 & 0.57 & 0.63 & 0.46 & 0.56
\end{tabular}

Notes: Standard errors in parentheses. Significance level: $* * *$ at $1 \%, * *$ at $5 \%, *$ at $10 \%$

Table 3 shows OLS regression between the contracting institution proxy indexes and respectively log GDP per capita, credit to the private sector and ratio investment to GDP.

Regarding contracting institutions (EC and RI), they do not look to have an impact on economic growth and expansion of credit. 
Regarding the ratio of investment to GDP, there is evidence of strong positive relationship of Enforcing Contracts with Gross Capital Formation. An increase of one unit in the quality of EC Index has an impact of $+1.3 \%$ in the gross invested capital.

Contrary to our expectations, EC does not seem to have a relationship with gross fixed capital formation; an increase in invested capital is not reflected in fixed long-term assets.

Resolving insolvency and investing capital do not result in having a relationship between them.

\section{Conclusion}

The analysis on GDP per capita, credit to private sector and investment ratio to GDP in Albania for the period from 1993 to 2015 shows similar results with those of other works in this field of study.

Property rights measured by PI and Polity IV as indicators of constrains on executive, have a significant positive effect on two major economic outcomes, the GDP per capita and credit to private sector. No effect of property rights on the ratio investment to GDP is found, although further analyses confirm a positive effect on foreign direct investment (Table 4 and Table 5).

The evidence of positive relationship between property rights and economic growth may lead to discussions on how this influence is explicated. An important consideration to be taken into account is that safe property rights are symptomatic of the rule of law and so, they are part of a broader context. The indexes used are indicative of the protection of property rights, but they also measure the level of democracy, business protection, legitimacy of institutions etc. Each of them plays a positive role in economic development, so it is quite evident the mutual influence between institutions and economy. Better institutions lead to economic growth, but a wealthier society demands responsibility and accountability from its institutions.

In this paper it is noted that contracting institutions have a limited impact (enforcing contracts on gross capital formation) or no impact on the economic outcomes considered. A possible explanation is that individuals have different instruments to reduce the risks of loss following failure to comply with the contractual terms by the counterparty. The creditor may apply a higher interest rate to a riskier debtor or hold a mortgage as a security for debt. Operators may decide to change the terms of the contract by extending the repayment term or transforming the debt into invested capital i.e. transforming the creditor into a shareholder. In Albania, investors in the construction sector in financial difficulties may compensate the suppliers by offering them apartments they have built; a trader may transfer to the creditor part of goods he has bought. The possible solutions to the adverse conditions 
of contracting institutions are far wider than the possible solutions in case of deterioration of property rights institutions.

\section{References:}

1. Acemoglu, D., \& Johnson, S. (2005). Unbundling Institutions. Journal of Political Economy , 113 (5), 949-995.

2. Acemoglu, D., Johnson, S., \& Robinson, J. (2005). Institutions as a fundamental cause of long-run growth. In P. Aghion, \& S. Durlauf (A cura di), Handbook of Economoc Growth (p. 385-472).

3. ALUIZNI. (2015, March 27). Ministria e Zhvillimit Urban - Agjensia e Legalizimit, Urbanizimit dhe Integrimit te Zonave/Ndertimeve Informale. Tratto il giorno $04 \quad 17,2017$ da http://www.aluizni.gov.al/deklarate-per-shtyp-mbi-legalizimin-endertimeve-pa-leje-nga-institucionet-shteterore/

4. Barro, R. (1998). Determinants of Economic Growth: A CrossCountry Empirical Study (1 ed.). (T. M. Press, A cura di) MIT Press Books.

5. Buehn, A., \& Friedrich, S. (2010). New Estimates for the Shadow Economies All over the World. International Economic Journal .

6. Coase, R. H. (1937). The Nature of the Firm. Economica , 4, 386-405.

7. Coase, R. H. (1960). The Problem of Social Cost. Journal of Law and Economics , 3, 1-44.

8. de Soto, H. (2000). The mystery of capital: Why capitalism triumphs in the West and fails everywhere else. New York: Basic Books.

9. Djankov, S., Glaeser, E., La Porta, R., Lopez-de-Silanes, F., \& Shleifer, A. (2003). The new comparative economics. Journal of Comparative Economics , 31, 595-619.

10. Dougherty, C., \& Jorgenson, W. D. (1996). International Comparisons of the Sources of Economic Growth. American Economic Association Papers and Proceedings , 86, 25-29.

11. Greif, A. (1993). Contract enforceability and economic institutions in early trade: The Maghribi traders' coalition. The American economic review , 525-548.

12. Greif, A. (2006). Institutions and the Path to the Modern Economy: Lessons from Medieval Trade. New York: Cambridge University Press.

13. Greif, A., Milgrom, P., \& Weingast, B. R. (1994). Coordination, Commitment, and Enforcement: The Case of the Merchant. Guild. The Journal of Political Economy, 745-776.

14. Hayek, F. A. (1945). The Use of Knowledge in Society. American Economic Review, 35 (4), 519-30.

15. Hobbes, T. (1991). Leviathan. New York: Cambridge Univ. Press. 
16. Hobsbawn, E. J. (1996). The age of revolution 1789-1848 (6 ed.). New York.

17. Instat Albania. (2014). Migracioni ne Shqiperi. Tirane: INSTAT Instituti i Statistikave.

18. Kerekes, C., \& Williamson, C. (2008). Unveiling de Soto's Mystery: Property Rights, Capital, and Development. Journal of Institutional Economics , 4 (3), 299-325.

19. Mankiw, N. G., Romer, D., \& Weil, D. (1992). A Contribution to the Empirics of Economic Growth. Quarterly Journal of Economics , 110 (3), 681-713.

20. Menger, C. ([1871] 1976). Principles of Economics. Auburn, Alabama: Ludwig von Mises Institute.

21. Mises, L. v. ([1940] 1998). Human Action. A Treatise on Economics (4 ed.). (B. B. Greave, A cura di) Auburn, Alabama: The Ludwig von Mises Institute.

22. North, D. C. (1991). Institutions. The Journal of Economic Perspectives , 97-112.

23. North, D. C. (1981). Structure and Change in Economic History. New York: Norton.

24. Ogilvie, S., \& Carus, A. W. (2014). Institutions and Economic Growth in Historical Perspective. In P. Aghion, \& S. N. Durlauf (A cura di), Handbook of Economic Growth (2 ed.). Elsevier B.V.

25. Olson, M. (2000). Power and Prosperity: Outgrowing Communist and Capitalist. Oxford: Oxford University Press.

26. Rutherford, M. (2001). Institutional Economics: Then and Now. Journal of Economic Perspectives , 15 (3), 185-90.

27. Schultz, T. W. (1961). Investment in Human Capital. The American Economic Review , 51 (1), 1-17.

28. Smith, A. ([1776] 1991). The Wealth of Nations. New York, NY: Alfred A.Knopf, Everyman's Library.

29. The World Bank. (s.d.). Tratto il giorno January 31, 2017 da http://data.worldbank.org/country/albania?view=chart

30. Transparency International. (s.d.). Corruption Perceptions Index 2016. Tratto il giorno January 28, 2017 da http://www.transparency.org/news/feature/corruption_perceptions_in dex_2016

31. Williamson, O. E. (2002). The Theory of the Firm as Governance Structure: From Choice to Contract . The Journal of Economic Perspectives , 16 (3), 171-195.

32. Williamson, O. (1985). The Economic Institutions of Capitalism. New York: The Free Press. 


\section{Williamson, O. (2000). The New Institutional Economics: Taking Stock, Looking Ahead . Journal of Economic Literature , 38 (3), 595- 613.}

\section{Appendix}

Table 1.a: Variable Definitions and Sources

\begin{tabular}{ccc} 
Variable & Abbreviation & Definition \\
\hline Gross Domestic & GDP per & GDP per capita is gross domestic product divided by midyear \\
product per capita & capita & $\begin{array}{c}\text { population. GDP is the sum of gross value added by all } \\
\text { resident producers in the economy plus any product taxes and } \\
\text { minus any subsidies not included in the value of the products. } \\
\text { It is calculated without making deductions for depreciation of } \\
\text { fabricated assets or for depletion and degradation of natural } \\
\text { resources. Data are in current U.S. dollars. } \\
\text { Source: World Bank }\end{array}$ \\
&
\end{tabular}

Source: World Bank

\begin{tabular}{|c|c|c|}
\hline $\begin{array}{l}\text { Domestic credit to } \\
\text { private sector }\end{array}$ & & $\begin{array}{l}\text { Domestic credit to private sector refers to financial resources } \\
\text { provided to the private sector by financial corporations, such } \\
\text { as through loans, purchases of no equity securities, and trade } \\
\text { credits and other accounts receivable that establish a claim for } \\
\text { repayment. For some countries these claims include credit to } \\
\text { public enterprises. The financial corporations include } \\
\text { monetary authorities and deposit money banks, as well as } \\
\text { other financial corporations where data are available } \\
\text { (including corporations that do not accept transferable } \\
\text { deposits but do incur such liabilities as time and savings } \\
\text { deposits). Examples of other financial corporations are } \\
\text { finance and leasing companies, money lenders, insurance } \\
\text { corporations, pension funds, and foreign exchange } \\
\text { companies. }\end{array}$ \\
\hline $\begin{array}{l}\text { Gross Capital } \\
\text { Formation }\end{array}$ & GCF & $\begin{array}{l}\text { Gross capital formation (formerly gross domestic investment) } \\
\text { consists of outlays on additions to the fixed assets of the } \\
\text { economy plus net changes in the level of inventories. Fixed } \\
\text { assets include land improvements (fences, ditches, drains, and } \\
\text { so on); plant, machinery, and equipment purchases; and the } \\
\text { construction of roads, railways, and the like, including } \\
\text { schools, offices, hospitals, private residential dwellings, and } \\
\text { commercial and industrial buildings. Inventories are stocks of } \\
\text { goods held by firms to meet temporary or unexpected } \\
\text { fluctuations in production or sales, and "work in progress." } \\
\text { According to the } 1993 \text { SNA, net acquisitions of valuables are } \\
\text { also considered capital formation. }\end{array}$ \\
\hline $\begin{array}{c}\text { Gross Fixed } \\
\text { Capital Formation }\end{array}$ & GFCF & $\begin{array}{l}\text { Gross fixed capital formation (formerly gross domestic fixed } \\
\text { investment) includes land improvements (fences, ditches, } \\
\text { drains, and so on); plant, machinery, and equipment } \\
\text { purchases; and the construction of roads, railways, and the } \\
\text { like, including schools, offices, hospitals, private residential } \\
\text { dwellings, and commercial and industrial buildings. } \\
\text { According to the } 1993 \text { SNA, net acquisitions of valuables are } \\
\text { also considered capital formation. }\end{array}$ \\
\hline $\begin{array}{l}\text { Enforcing } \\
\text { Contracts }\end{array}$ & EC & $\begin{array}{l}\text { The enforcing contracts indicator measures the time and cost } \\
\text { for resolving a commercial dispute through a local first- } \\
\text { instance court, and the quality of judicial processes index, } \\
\text { evaluating whether each economy has adopted a series of }\end{array}$ \\
\hline
\end{tabular}


Resolving

Insolvency

good practices that promote quality and efficiency in the court system.

RI Doing Business studies the time, cost and outcome of insolvency proceedings involving domestic legal entities.

These variables are used to calculate the recovery rate, which is recorded as cents on the dollar recovered by secured creditors through reorganization, liquidation or debt enforcement (foreclosure or receivership) proceedings. Source: World Bank

\begin{tabular}{|c|c|c|}
\hline Polity IV Index & Polity IV & $\begin{array}{l}\text { The Polity scheme consists of six component measures that } \\
\text { record key qualities of executive recruitment, constraints on } \\
\text { executive authority and political competition in different } \\
\text { countries. It also records changes in the institutionalized } \\
\text { qualities of governing authority. } \\
\text { Source: Center for Systemic Peace and Societal-Systems } \\
\text { Research Inc. }\end{array}$ \\
\hline $\begin{array}{l}\text { Heritage Property } \\
\text { Index }\end{array}$ & HPI & $\begin{array}{l}\text { The principles of economic freedom are measured in the } \\
\text { Index of Economic Freedom, a guide published annually. The } \\
\text { Index covers } 12 \text { quantitative and qualitative factors grouped } \\
\text { in four categories such as rule of law, government size, } \\
\text { regulatory efficiency, open markets. } \\
\text { Source: The Heritage Foundation }\end{array}$ \\
\hline $\begin{array}{l}\text { Government } \\
\text { Consumption }\end{array}$ & & $\begin{array}{l}\text { General government final consumption expenditure (formerly } \\
\text { general government consumption) includes all government } \\
\text { current expenditures for purchases of goods and services } \\
\text { (including compensation of employees). It also includes most } \\
\text { expenditure on national defence and security, but excludes } \\
\text { government military expenditures that are part of government } \\
\text { capital formation. } \\
\text { Source: World Bank }\end{array}$ \\
\hline Inflation & & Source: Bank of Albania \\
\hline
\end{tabular}

Table 4

\begin{tabular}{c|cccccc}
\hline FDI & Coef. & Std. Err. & $\mathrm{t}$ & $\mathrm{P}>\mathrm{t}$ & {$[95 \%$ Conf. } & Interval] \\
\hline PolityIV & 1.316 .015 & .3043634 & 4.32 & 0.000 & .6789753 & 1.953 .055 \\
Governmentcons & .2540267 & .3669475 & 0.69 & 0.497 & -.5140033 & 1.022 .057 \\
LnInflation & .2143313 & .5681455 & 0.38 & 0.710 & -.9748109 & 1.403 .474 \\
_cons & -7.145 .402 & 4.730 .444 & -1.51 & 0.147 & -1.704 .634 & 2.755 .531 \\
\hline
\end{tabular}

Table 5

\begin{tabular}{c|cccccc}
\hline FDI & Coef. & Std. Err. & $\mathrm{t}$ & $\mathrm{P}>\mathrm{t}$ & {$[95 \%$ Conf. } & Interval] \\
\hline HPIoverallscore & .5641862 & .0769654 & 7.33 & 0.000 & .4018034 & .7265691 \\
Governmentcons & .5392149 & .3900198 & 1.38 & 0.185 & -.2836548 & 1.362 .085 \\
LnInflation & .3519539 & .4408339 & 0.80 & 0.436 & -.5781243 & 1.282 .032 \\
cons & -3.412 .564 & 6.730 .517 & -5.07 & 0.000 & -48.32579 & -19.92549 \\
\hline
\end{tabular}


Table 6: Econometric Tests

\begin{tabular}{|c|c|c|c|c|c|c|}
\hline Independent Variable HPI & & Skewnes & $\begin{array}{l}\text { /Kurtosis t } \\
\text { Jormality }\end{array}$ & sts for & & $\begin{array}{c}\text { Breusch- } \\
\text { Pagan / } \\
\text { Cook- } \\
\text { Weisberg } \\
\text { test for } \\
\text { heteroskedast } \\
\text { icity } \\
\end{array}$ \\
\hline Variable & $\begin{array}{c}\mathrm{Ob} \\
\mathrm{s}\end{array}$ & $\begin{array}{l}\text { Pr(Skewn } \\
\text { ess) }\end{array}$ & $\begin{array}{l}\text { Pr(Kurto } \\
\text { sis) }\end{array}$ & $\begin{array}{c}\operatorname{adj} \\
\operatorname{chi} 2(2)\end{array}$ & $\begin{array}{l}\text { Prob }>c \\
\text { hi } 2\end{array}$ & Prob > chi 2 \\
\hline GDP per capita current $\$$ & 21 & 0.3380 & & & & 0.7094 \\
\hline $\begin{array}{l}\text { Domestic credit to private sector } \\
\text { ( } \% \text { of GDP) }\end{array}$ & 21 & 0.6945 & 0.1952 & 2.04 & 0.3603 & 0.8752 \\
\hline $\begin{array}{l}\text { Gross Capital Formation (\% of } \\
\text { GDP) }\end{array}$ & 21 & 0.6875 & 0.1452 & 2.56 & 0.2774 & 0.2489 \\
\hline $\begin{array}{l}\text { Gross Fixed Capital Format. (\% } \\
\text { of GDP) }\end{array}$ & 21 & 0.8667 & 0.1246 & 2.69 & 0.2612 & 0.1526 \\
\hline Foreigndirectinvestmentnet & 21 & 0.1378 & 0.9195 & 2.48 & 0.2890 & 0.7790 \\
\hline $\begin{array}{l}\text { Independent Variable Enforcing } \\
\text { Contracts }\end{array}$ & & Skewnes & $\begin{array}{l}\text { /Kurtosis t } \\
\text { Jormality }\end{array}$ & ists for & & $\begin{array}{c}\text { Breusch- } \\
\text { Pagan / } \\
\text { Cook- } \\
\text { Weisberg } \\
\text { test for } \\
\text { heteroskedast } \\
\text { icity } \\
\end{array}$ \\
\hline Variable & $\mathrm{Ob}$ & $\begin{array}{l}\text { Pr(Skewn } \\
\text { ess) }\end{array}$ & $\begin{array}{l}\text { Pr(Kurto } \\
\text { sis) }\end{array}$ & $\begin{array}{c}\text { adj } \\
\text { chi2(2) }\end{array}$ & $\begin{array}{l}\text { Prob>c } \\
\text { hi2 }\end{array}$ & Prob > chi2 \\
\hline GDP per capita current $\$$ & 13 & 0.1695 & 0.8401 & 2.24 & 0.3255 & 0.3378 \\
\hline $\begin{array}{l}\text { Domestic credit to private sector } \\
\text { (\% of GDP) }\end{array}$ & 13 & 0.1318 & 0.7629 & 2.78 & 0.2488 & 0.3585 \\
\hline $\begin{array}{l}\text { Gross Capital Formation (\% of } \\
\text { GDP) }\end{array}$ & 13 & 0.9947 & 0.6273 & 0.24 & 0.8888 & 0.7517 \\
\hline $\begin{array}{l}\text { Gross Fixed Capital Format. (\% } \\
\text { of GDP) }\end{array}$ & 13 & 0.8562 & 0.2935 & 1.28 & 0.5285 & 0.8629 \\
\hline Foreigndirectinvestmentnet & 13 & 0.5531 & 0.6029 & 0.66 & 0.7180 & 0.5982 \\
\hline $\begin{array}{l}\text { Independent Variable Resolving } \\
\text { Insolvency }\end{array}$ & \multicolumn{5}{|c|}{$\begin{array}{l}\text { Skewness/Kurtosis tests for } \\
\text { Normality }\end{array}$} & $\begin{array}{c}\text { Breusch- } \\
\text { Pagan / } \\
\text { Cook- } \\
\text { Weisberg } \\
\text { test for } \\
\text { heteroskedast } \\
\text { icity } \\
\end{array}$ \\
\hline Variable & $\begin{array}{c}\mathrm{Ob} \\
\mathrm{s}\end{array}$ & Pr(Skewn & $\begin{array}{l}\operatorname{Pr}(\text { Kurto } \\
\text { sis) }\end{array}$ & $\begin{array}{c}\operatorname{adj} \\
\operatorname{chi} 2(2)\end{array}$ & $\begin{array}{l}\text { Prob>c } \\
\text { hi } 2\end{array}$ & Prob > chi2 \\
\hline GDP per capita cu & 13 & 0.2938 & 0.8346 & 1.29 & 0.5255 & 0.2097 \\
\hline $\begin{array}{l}\text { Domestic credit to private sector } \\
\text { (\% of GDP) }\end{array}$ & 13 & 0.2026 & 0.7461 & 2.00 & 0.3682 & 0.2160 \\
\hline $\begin{array}{l}\text { Gross Capital Formation (\% of } \\
\text { GDP) }\end{array}$ & 13 & 0.4287 & 0.5274 & 1.14 & 0.5651 & 0.5010 \\
\hline $\begin{array}{l}\text { Gross Fixed Capital Format. (\% } \\
\text { of GDP) }\end{array}$ & 13 & 0.6646 & 0.8336 & 0.23 & 0.8904 & 0.4627 \\
\hline Foreigndirectinvestmentnet & 13 & 0.5531 & 0.6029 & 0.66 & 0.7180 & 0.5982 \\
\hline
\end{tabular}


Table 7 Econometric Tests: Multicollinearity

\begin{tabular}{|c|c|c|c|c|c|c|c|}
\hline & PolityIV & Govern $\sim \mathrm{t}$ & Infl $\sim \mathrm{n}$ & & HPIove e & Govern $\sim \mathrm{t}$ & Infl $\sim \mathrm{n}$ \\
\hline PolityIV & 1.0000 & & & HPIoverall e & 1.0000 & & \\
\hline Government $\mathrm{t}$ & -0.1822 & 1.0000 & & Government $\sim \mathrm{t}$ & 0.0283 & 1.0000 & \\
\hline \multirow[t]{2}{*}{ LnInflation } & -0.6273 & 0.2883 & 1.0000 & LnInflation & -0.5066 & 0.2883 & 1.0000 \\
\hline & Enforc $\sim \mathrm{F}$ & Govern $\sim \mathrm{t}$ & Infl $\sim \mathrm{n}$ & & Resolv $\sim \mathrm{F}$ & Govern $\sim \mathrm{t}$ & Infl $\sim \mathrm{n}$ \\
\hline EnforcingC $\sim \mathrm{F}$ & 1.0000 & & & ResolvingI F & 1.0000 & & \\
\hline Government $\sim \mathrm{t}$ & -0.0142 & 1.0000 & & Government $\sim \mathrm{t}$ & 0.0906 & 1.0000 & \\
\hline LnInflation & 0.6772 & 0.2883 & 1.0000 & LnInflation & -0.6561 & 0.2883 & 1.0000 \\
\hline
\end{tabular}

